\title{
Faktor Yang Mepengaruhi Rasio Pembayaran Dividen Perusahaan BEI
}

\author{
Hesniati $^{1)}$ \\ Universitas Internasional Batam \\ Hesniati.lec@uib.ac.id \\ Yopie Hendra ${ }^{2)}$ \\ Universitas Internasional Batam \\ Yopiehendra03@gmail.com
}

\begin{abstract}
Abstrak
Tujuan dari penelitian ini adalah untuk menganalisis pengaruh profitabilitas, ukuran perusahaan, likuiditas, hutang, dan pertumbuhan penjualan terhadap rasio pembayaran dividen. Sampel yang digunakan pada penelitian ini adalah perusahaan yang terdaftar pada Bursa Efek Indonesia yang membayar dividen 5 tahun berturut-turut. Metode analisis data yang digunakan pada penelitian ini adalah regresi berganda. Penelitian ini dilakukan dengan total 77 sampel perusahaan yang terdaftar di Bursa Efek Indonesia dari period tahun 2012 sampai dengan 2016. Hasil pengujian data menemukan bahwa profitabilitas dan ukuran perusahaan berpengaruh signifikan positif terhadap rasio pembayaran dividen, sedangkan likuiditas dan pertumbuhan penjualan mempunyai pengaruh yang signifikan negatif terhadap rasio pembayaran dividen.
\end{abstract}

Kata Kunci rasio pembayaran dividen, profitabilitas, ukuran perusahaan, likuiditas, hutang, pertumbuhan penjualan

\section{PENDAHULUAN}

Dividen merupakan pengembalian aktual bagi para pemegang saham yang melakukan investasi terhadap saham sebuah perusahaan. Umumnya pembayaran dividen juga cenderung mengalami pertumbuhan dan perusahaan yang membayar dividen juga mendapatkan reputasi yang baik ketika meningkatkan pembayaran deviden dari tahun ke tahun, sehingga kebijakan dividen sangat diperhatikan oleh pihak manajemen perusahaan.

Kebijakan pembayaran dividen diukur dengan mengunakan dividend payout ratio, dimana rasio ini menunjukkan seberapa besar rasio persentase dari hasil laba yang diperoleh perusahaan yang kemudian didistribusikan dalam bentuk dividen tunai kepada para investor atau pemegang saham. Rasio pembayaran dividen akan mempengaruhi keputusan para investor untuk menanamkan modal dan disisi lain akan berpengaruh pada kondisi keuangan perusahaan. Jika perusahaan menaikkan dividend payout ratio tentunya dapat meningkatkan harga saham dan memberikan sinyal yang baik kepada para investor bahwa perusahaan mempunyai kemampuan pembayaran dividen yang baik dimasa yang akan datang. Akan tetapi, dengan adanya kenaikan dividend payout ratio akan mengurangi sumber dana internal yang tersedia untuk investasi kembali sehingga dapat menghambat tingkat pertumbuhan dimasa yang akan datang dan mengakibatkan turunnya harga saham perusahaan.

Emiten PT Lion Metal Works Tbk. merupakan produsen alat logam yang membagikan dividen atas laba bersih tahun 2016 kepada para pemegang saham dengan sebesar Rp20,8 miliar atau senilai Rp40 per saham. Penjualan pada emiten ini sebesar Rp379,14 miliar dan turun sebesar 2,6\% dibandingkan dengan tahun 2015 yang senilai Rp389,25 miliar. Seiring dengan turunnya penjualan, laba perseroan pun turun $8 \%$ dibandingkan dengan tahun 2015. Akan tetapi, emiten tersebut justru membagikan rasio dividen 
sebesar 49\% atas laba bersih perusahaan senilai Rp42,35 miliar yang lebih besar dibandingkan tahun 2015 hanya sebesar 45\% (Caesario, 2017).

Ternyata hal tersebut juga terjadi pada PT Gowa Makassar Toursm Development Tbk untuk membagikan dividen kepada pemegang saham meskipun pendapatan perusahaan mengalami penurunan. Emiten tersebut membagikan dividen setara Rp25 per saham dengan pendapatan yang menurun sebesar $9 \%$.

Dari kasus permasalahan di atas menjelaskan meskipun laba perusahaan mengalami penurunan namun perusahaan cenderung tetap membagikan dividen yang stabil dan mengalami peningkatan. Sehingga dapat disimpulkan bahwa tidak sepenuhnya kemampuan perusahaan dalam membayar dividen dapat diukur dari hasil laba yang diperoleh melainkan dari beberapa faktor-faktor lain yang mempengaruhi dividend payout ratio. Berdasarkan permasalahan adanya faktor-faktor yang mempengaruhi kebijakan pembayaran dividen yang telah dibahas diatas maka penulis sangat tertarik untuk melakukan penelitian mengenai faktor-faktor yang mempengaruhi pembayaran dividen pada perusahaan BEI.

\section{LANDASAN TEORI}

Patrick et al. (2017) melakukan penelitiannya untuk mengevaluasi faktor-faktor penentu kebijakan dividen perusahaan minyak di Nigeria. Untuk menyelidiki penelitian ini, data diperoleh dari sembilan perusahaan perminyakan di Nigeria mulai dari 2011-2014. Analisis data dengan menggunakan korelasi, analisis regresi dan statistik deskriptif. Variabel independen yang digunakan adalah Liquidity, Firm Size, Profitability dan Leverage untuk mempengaruhi variabel dependennya, yaitu Dividend Payout Ratio.

Hashim (2017) pada penelitiannya menyatakan tujuan melakukan penelitian tersebut untuk mengetahui adakah identifikasi faktor-faktor sebagai penentu kebijakan pembagian dividen pada 50 perusahaan properti yang terpilih dan terdaftar di Bursa Efek Malaysia dalam rentang semala 11 tahun dari tahun 2004 sampai 2014. Variabel Dividend Payout Ratio merupakan variabel dependen yang akan digunakan untuk mendukung hasil penelitian ini sedangkan variabel Liquidity, Size of Company, Profitability dan Leverage merupakan variabel independen.

Dalam hasil jurnal yang dikemukakan oleh Khan et al. (2016) melakukan pengujian mengenai dampak faktor-faktor terhadap keputusan pembagian dividen perusahaan. Penelitian ini menggunakan 60 data perusahaan dengan periode 2010 sampai 2014. Teknik penelitian yang digunakan dalam penelitian ini berupa teknik random sampling. Variabel independen dalam penelitian ini berupa Price Earning Ratio, Leverage, Liquidity, Profitability dan Firm Size.

Menurut John dan Muthusamy (2010) dalam hasil penelitiannya bertujuan untuk menguji kebijakan dividen perusahaan untuk industri kertas India. Variabel indenpenden yang digunakan untuk menguji variabel dependennya, yaitu dividend payout ratio pada perusahaan tersebut adalah Variabel Leverage, Return On Asset, Price Earnings Ratio, Cash Flow, Earnings Per Share, Market to Book Value Ratio, Liquidity dan Growth in Sales.

Badu (2013) menguji faktor-faktor penentu kebijakan pembayaran dividen lembaga keuangan terdaftar di Ghana dengan menggunakan fixed dan random effect. Data panel yang mencakup tahun 20052009 dari perusahaan terpilih yang digunakan untuk penelitian ini. Variabel independennya adalah Age of Firm, Liquidity dan Collateral Capacity.

Fitri et al. (2016) menguji pengaruh Variabel Debt to Equity Ratio, Growth Opportunities dan Return On Asset terhadap Dividen Payout Ratio. Untuk mendukung hasil penelitian tersebut maka sampel yang digunakan adalah perusahaan di Jakarta Islamic Index dalam kurun waktu selama 5 tahun, yaitu dari tahun 2009 sampai tahun 2014. Untuk menguji hasil penelitian tersebut maka diperlukan beberapa metode, yaitu menggunakan analisis data panel regresi dan model yang dipilih yang menggunakan model common effect.

Dalam hasil penelitian yang dikemukakan oleh Malik et al. (2013), yaitu mengenai faktor-faktor penentu rasio pembayaran dividen pada emiten di Bursa Efek Karachi dan merupakan bagian dari indeks KSE-100. Dengan menggunakan data panel dari 100 perusahaan keuangan dan non-keuangan selama periode 2007 sampai 2009. Untuk mempengaruhi kebijakan dividen dalam hasil penelitian ini, maka 
variabel independen yang digunakan adalah Growth, Leverage, Earning Per Share, Firm Size Liquidity dan Profitability.

Milhem (2016) menyelidiki tentang faktor-faktor penentu pembayaran dividen untuk semua bank di Jordan yang terdaftar di Bursa Efek Amman untuk jangka waktu 5 tahun dari 2009-2013 sebanyak 16 bank (13 konvensional dan 3 Syariah). Untuk menguji pengaruh faktor faktor yang mempengaruhi pembayaran dividen (variabel dependen), maka variabel independen yang diteliti adalah variabel Liquidity, Profitability, Firm Size, Price Earning Ratio dan Leverage.

Awad (2015) melakukan pengujian mengenai faktor-faktor penentu keputusan pembagian dividen pada emiten di Bursa Efek Kuwait. Untuk dapat menguji data dalam penelitian sampel ini maka diperlukan sampel penelitian sebanyak 56 perusahaan sektor keuangan yang terdaftar di Bursa Efek Kuwait dalam periode 4 tahun dari 2011 sampai 2014 dan data dianalisis dalam kerangka teknik regresi OLS. Variabel independen yang digunakan adalah Company Size, Profitability dan Financial Leverage.

Menurut penelitian oleh Maldajian dan Khoury (2014) dalam hasil penelitiannya menyelidiki mengenai faktor-faktor yang mempengaruhi besar kecilnya pembagian dividen pada emiten di Bursa Efek Beirut pada bidang perbankan Lebanon. Studi ini mempertimbangkan dampak pengaruh dari tujuh variabel independen, yaitu Profitability, Previous Year's Dividends, Firm Size, Liquidity, Firm Risk, Growth Opportunities dan Leverage. Data yang dijadikan sampel untuk mendukung hasil penelitian yang akan diuji adalah dari emiten di Bursa Efek Beirut antara tahun 2005 sampai 2011 pada bidang perbankan.

\section{Dividend Payout Ratio}

Menurut Ahmad dan Wardani (2014) menyatakan bahwa Dividend Payout Ratio merupakan kebijakan pembayaran dividen yang menunjukkan seberapa besar rasio persentase dari laba yang diperoleh perusahaan yang kemudian didistribusikan dalam bentuk dividen tunai kepada para investor atau pemegang saham. Dividend payout ratio merupakan variabel yang mengukur rasio persentase laba bersih yang diperoleh perusahaan yang kemudian didistribusikan kepada pemegang saham atau para investor dalam bentuk dividen tunai sepanjang tahun (Ehsan, et al., 2013).

\section{Profitabilitas}

Dalam hasil penelitian yang diuji oleh Fitri et al. (2016) menemukan bahwa variabel profitabilitas memiliki pengaruh signifikan positif dengan variabel dividend payout ratio. Dengan kata lain, perusahaan yang memiliki tingkat profitabilitas tinggi cenderung membuat perusahaan tersebut mampu membayar dividen yang tinggi dibandingkan perusahaan yang memiliki profitabilitas yang rendah sehingga para investor cenderung menanamkan modal pada perusahaan yang memiliki tingkat profitabilitas tinggi agar mendapatkan keuntungan yang lebih banyak. Hal ini menunjukkan bahwa perusahaan selalu berupaya untuk memperbaiki citra perusahaan melalui pembayaran dividen. Dari hasil penelitian yang telah disebutkan, terdapat beberapa penelitian lain yang menemukan hasil yang sama dan sesuai dengan hipotesis tersebut, yaitu penelitian oleh Leon dan Putra (2014), Tabari dan Shirazi (2015), Amidu dan Abor (2006), Obembe et al. (2014), Ahmad dan Wardani (2014), Tahir dan Mushtaq (2016), Yusuf dan Muhammed (2015), Labhane dan Das (2015), Patrick et al. (2017), Issa (2015), Malik et al. (2013), Milhem (2016), Wijaya dan Felix (2017), Ehsan et al. (2013) dan Aftab et al. (2017).

Dalam hasil penelitian yang diuji oleh Khan et al. (2016) menemukan bahwa hubungan antara variabel profitabilitas terhadap dividend payout ratio memiliki pengaruh signifikan yang bernilai negatif. Dikarenakan perusahaan yang memiliki profit yang tinggi akan menahan laba internal mereka untuk berinvestasi kembali pada perusahaan untuk mendapatkan keuntungan yang lebih sehingga tindakan perusahaan dalam membayar dividen kepada pemegang saham menjadi berkurang. Dan hasil hipotesa tersebut juga didukung oleh beberapa penelitian, yaitu John dan Muthusamy (2010), Gill et al. (2010), Thu et al. (2013), Demirgunes (2015), Maldajian dan Khoury (2014), Sanjari dan Zarei (2015), Hosain (2016) dan Hashim (2017).

Sedangkan hasil penelitian yang ditemukan oleh Badu (2013) menunjukkan bahwa hubungan antara profitabilitas terhadap dividend payout ratio dinyatakan tidak memiliki pengaruh yang signifikan. Hal ini mungkin menunjukkan bahwa perusahaan dalam membayar dividen tidak harus mempertimbangkan tingkat keuntungannya melainkan manajer perusahaan yang berpikir tepat untuk melakukannya. Hasil 
penelitian tersebut didukung oleh beberapa penelitian lainnya, yaitu penelitian oleh Komrattanapanya dan Suntraruk (2013), Rafique (2012), Anil dan Kapoor (2008) dan Saeed et al. (2014).

\section{Firm Size}

Dalam hasil penelitian yang diuji oleh Komrattanapanya dan Suntraruk (2013) menemukan bahwa hubungan yang terdapat antara firm size dan dividend payout ratio memiliki pengaruh signifikan positif. Perusahaan yang memiliki kapasitas atau ukuran yang lebih besar cenderung akan memberikan dividen yang lebih tinggi dibandingkan perusahaan yang memiliki kapastias atau ukuran kecil dikarenakan perusahaan yang besar memiliki kemudahan akses untuk masuk dalam perekonomian pasar modal sehingga perusahaan mampu memperoleh dana dan keuntungan yang lebih besar. Perusahaan dengan ukuran yang besar cenderung tidak memerlukan dana yang banyak untuk memperluas operasi mereka dikarenakan perusahaan besar memiliki peluang pertumbuhan yang lebih rendah daripada perusahaan kecil. Perusahaan kecil membuat manajer perusahaan cenderung menahan laba untuk melakukan investasi yang lebih baru untuk perkembangan perusahaan. Dari hasil penelitian tersebut, terdapat beberapa penelitian lainnya yang mendukung hipotesis tersebut, yaitu penelitian oleh Ahmad dan Wardani (2014), Tahir dan Mushtaq (2016), Tabari dan Shirazi (2015), Malik et al. (2013), Obembe et al. (2014), Maldajian dan Khoury (2014), Rafique (2012), Labhane dan Das (2015), Milhem (2016), Sanjari dan Zarei (2015) dan Awad (2015).

Sedangkan hasil uji yang dilakukan oleh penelitian Thu et al. (2013) menyatakan bahwa hubungan antara variabel firm size terhadap dividend payout ratio memiliki pengaruh signifikan namun bernilai negatif. Sebuah perusahaan yang besar akan masuk dalam kondisi ekonomi yang sangat berpengaruh bahan operasional sehingga dana akan dialokasikan untuk membiayai bahan operasional dibandingkan membayar dividen. Hal ini terjadi dikarenakan perusahaan akan mengambil keputusan tersebut terkait keuntungan yang diperoleh sehingga perusahaan yang besar dan memiliki hasil investasi yang baik tidak menjamin dapat membayar dividen yang besar. Hasil penelitian hipotesa tersebut juga didukung oleh Ehsan et al. (2013) dan Ullah et al. (2012). Namun terdapat beberapa penelitian dalam hasil uji datanya menemukan bahwa hubungan antara variabel firm size terhadap dividend payout ratio tidak memiliki pengaruh yang signifikan, yaitu penelitian oleh Yusuf dan Muhammed (2015), Patrick et al. (2017), Wara (2015), Hosain (2016), Khan et al. (2016), Anil dan Kapoor (2008), Saeed et al. (2014), Khan dan Ahmad (2017), Wijaya dan Felix (2017) dan Hashim (2017).

\section{Likuiditas}

Likuiditas merupakan kemampuan perusahaan untuk memenuhi kewajibannya finansialnya yang jatuh tempo pada waktu jangka pendek. Suatu perusahaan yang dapat menjalankan kewajibannya dengan lancar yang tepat pada waktunya akan memberikan pandangan yang baik kepada perusahaan tersebut. Dalam hasil uji penelitian yang dikemukakan oleh Badu (2013) menunjukkan bahwa hubungan antara likuiditas terhadap dividend payout ratio memiliki pengaruh signifikan positif. Perusahaan dengan tingkat likuiditas yang tinggi berarti memiliki arus kas yang baik dan stabil dan cenderung memberikan gambaran bahwa perusahaan mampu memenuhi kewajibannya pada waktu jatuh tempo juga memiliki kemampuan dalam membayar dividen lebih tinggi dibandingkan dengan perusahaan yang memiliki pendapatan tidak stabil atau likuiditas yang buruk yang menyebabkan pembagian dividen yang rendah. Hasil penelitian tersebut juga konsisten dengan Tabari dan Shirazi (2015), Hosain (2016), Sanjari dan Zarei (2015) dan Malik et al. (2013).

Namun dalam hasil penelitian yang ditemukan oleh Khan et al. (2016) menunjukkan bahwa hubungan antara variabel likuiditas terhadap dividend payout ratio memiliki pengaruh signifikan yang negative, hal ini dikarenakan semakin banyak uang dalam bentuk dividen yang akan dibayarkan kepada para investor akan mengurangi kas yang ada pada perusahaan sehingga perusahaan mengalami kesulitan dalam pembiayaan perusahaan. Perusahaan yang memiliki likuiditas yang tinggi lebih memilih menahan laba untuk melakukan investasi kembali untuk mengantisipasi pada keperluan atau permasalahan yang akan terjadi di masa mendatang dan melaksanakan kewajibannya untuk membayar utang kepada kreditur. Sehingga untuk mempertahankan likuiditas yang tinggi maka perusahaan cenderung menurunkan rasio pembayaran dividen. Dan hasil penelitian hipotesa tersebut didukung oleh hasil penelitian lainnya, yaitu 
penelitian oleh Ahmad dan Wardani (2014), John dan Muthusamy (2010) dan Yusuf dan Muhammed (2015). Namun terdapat beberapa penelitian dalam hasil ujinya menyatakan bahwa likuiditas tidak memiliki hubungan signifikan terhadap dividend payout ratio adalah Tahir dan Mushtaq (2016), Labhane dan Das (2015), Patrick et al. (2017), Maldajian dan Khoury (2014), Demirgunes (2015), Komrattanapanya dan Suntraruk (2013), Milhem (2016), Wijaya dan Felix (2017) dan Hashim (2017).

5. Leverage

Dalam hasil penelitian yang dilakukan oleh Malik et al. (2013) menunjukkan bahwa variabel leverage memiliki pengaruh signifikan negatif terhadap dividend payout ratio. Perusahaan yang menggunakan modal sendiri untuk membiayai operasional perusahaan memiliki resiko lebih kecil daripada perusahaan menggunakan hutang yang akan meningkatkan resiko yang harus ditanggung perusahaan. Dengan kata lain perusahaan yang memiliki rasio leverage yang tinggi akan berdampak pada pembayaran dividen menjadi lebih rendah untuk memenuhi tanggung jawab mereka terhadap kreditur. Dengan maksud untuk mengurangi ketergantungan pada pinjamana dana eksternal. Hasil penelitian tersebut juga didukung oleh beberapa penelitian lainnya, yaitu penelitian oleh Gill et al. (2010), Hosain (2016), Ahmad dan Wardani (2014), John dan Muthusamy (2010), Khan et al. (2016), Labhane dan Das (2015), Hosain (2016), Komrattanapanya dan Suntraruk (2013), Ehsan et al. (2013), Tahir dan Mushtaq (2016) dan Ullah et al. (2012).

Sedangkan hasil penelitian yang diuji oleh Awad (2015) menemukan bahwa variabel leverage memiliki pengaruh signifikan positif terhadap variabel dividend payout ratio. Perusahaan dapat menggunakan utang untuk membayar dividen kepada pemegang saham untuk memberikan citra reputasi yang baik pada perusahaan dan mendapatkan ketertarikan para investor untuk menanamkan modal saham pada perusahaan tersebut dikarenakan perusahaan yang memiliki tingkat leverage yang tinggi mampu membayar hutang dengan baik serta membayar dividen dengan baik. Dan hasil hipotesis penelitian tersebut didukung oleh penelitian Sanjari dan Zarei (2015) dan Thu et al. (2013).

Namun menurut Leon dan Putra (2014) dalam hasil penelitiannya menemukan variabel leverage tidak memiliki pengaruh signifikan terhadap variabel dividend payout ratio. Hal ini dikarenakan perusahaan tidak menggunakan hutang untuk membayar dividen melainkan menggunakan profitabilitas untuk membayar dividen perusahaan. Dalam hasil penelitian tersebut ternyata didukung kuat oleh beberapa hasil penelitian lainnya, yaitu Obembe et al. (2014), Yusuf dan Muhammed (2015), Patrick et al. (2017), Wara (2015), Maldajian dan Khoury (2014), Yusuf (2015), Rafique (2012), Maldajian dan Khoury (2014), Fitri et al. (2016), Milhem (2016), Saeed et al. (2014), Khan dan Ahmad (2017), Wijaya dan Felix (2017) dan Hashim (2017).

\section{Sales Growth}

Dalam hasil penelitian yang dilakukan oleh Hosain (2016) menemukan bahwa hubungan antara variabel growth terhadap dividend payout ratio memiliki pengaruh signifikan negative, hal ini dikarenakan meningkatnya pertumbuhan perusahaan yang semakin tinggi akan membutuhkan lebih banyak dana untuk membiayai pertumbuhan perusahaan dalam berinvestasi proyek-proyeknya sehingga perusahaan akan mempertahankan proporsi pendapatan mereka yang lebih besar dengan membayar dividen yang rendah. Dan dalam hasil penelitian menurut Thu et al. (2013) menemukan bahwa hubungan antara sales growth dan dividend payout ratio terdapat pengaruh singifikan negatif. Jika perusahaan dapat mengantisipasi pertumbuhan di masa depan atau di masa lalu dengan cepat, maka perusahaan cenderung menghemat dana daripada meminjam dana dari pasar modal dengan bunga atau biaya yang lebih tinggi untuk berinvestasi kembali dengan menetapkan rasio pembayaran dividen yang lebih rendah.

Sedangkan dalam hasil penelitian yang dilakukan oleh Tahir dan Mushtaq (2016) menyampaikan bahwa hubungan antara sales growth dengan dividend payout ratio memiliki signifikan positif. Perusahaan yang memiliki peningkatan pada hasil penjualannya diharapkan mendapatkan keuntungan yang diperoleh sehingga menghasilkan dana yang banyak untuk memiliki kemampuan membayar dividen kepada para investor. Hubungan positif pertumbuhan penjualan dengan dividend payout memberikan bukti sebagai alat pemberi sinyal untuk menyampaikan pertumbuhan perusahaan di masa depan kepada 
para investor. Hasil penelitian tersebut didukung oleh penelitian Tabari dan Shirazi (2015) dan Musiega et al. (2013).

Terdapat beberapa penelitian dalam hasil ujinya menyatakan bahwa hubungan antara variabel sales growth terhadap dividend payout ratio memiliki pengaruh signifikan negatif, yaitu penelitian John dan Muthusamy (2010), Amidu dan Abor (2006), Sanjari dan Zarei (2015), Wara (2015), Demirgunes (2015), Malik et al. (2013), Maldajian dan Khoury (2014), Fitri et al. (2016) dan Wijaya dan Felix (2017). Sedangkan hasil yang menyatakan bahwa hubungan antara variabel sales growth terhadap dividend payout ratio yang tidak memiliki pengaruh signifikan didukung oleh penelitian Komrattanapanya dan Suntraruk (2013), Gill et al. (2010), Ahmad dan Wardani (2014), Issa (2015), Leon dan Putra (2014), Rafique (2012), Obembe et al. (2014), Badu (2013) dan Aftab et al. (2017).

\section{Perumusan Hipotesis}

$\mathrm{H}_{1}$ : $\quad$ Profitability memiliki pengaruh signifikan positif terhadap Dividend Payout Ratio.

$\mathrm{H}_{2}: \quad$ Firm Size memiliki pengaruh signifikan positif terhadap Dividend Payout Ratio.

$\mathrm{H}_{3}$ : Liquidity memiliki pengaruh signifikan positif terhadap Dividend Payout Ratio.

$\mathrm{H}_{4}$ : Leverage memiliki pengaruh signifikan negatif terhadap Dividend Payout Ratio.

$\mathrm{H}_{5}$ : $\quad$ Sales Growth memiliki pengaruh signifikan negatif terhadap Dividend Payout Ratio.

\section{METODE PENELITIAN}

Penelitian ini termasuk ke dalam penelitian kuantitatif dimana pengumpulan data, penafsiran dan penampilan hasilnya diwujudkan dalam bentuk angka-angka. Tujuan dari penelitian ini adalah untuk menguji signifikansi pengaruh antara variabel independen profitability, firm size, liquidity, leverage dan sales growth terhadap variabel dependen berupa dividend payout ratio.

Objek yang diambil untuk meneliti data adalah perusahaan yang memiliki laporan keuangan tahunan yang telah disusun dan terdaftar di BEI selama periode 2012 sampai 2016. Metode pengambilan sampel merupakan metode non-probability sampling yaitu memilih sampel secara tidak acak dengan cara purposive sampling, yaitu memiliki tujuan atau target tertentu. Adapun kriteria dalam pemilihan objek penelitian yang diambil adalah sebagai berikut:

1. Perusahaan Indonesia yang terdaftar di BEI selama 5 tahun periode dari tahun 2012-2016.

2. Perusahaan yang mempunyai laporan keuangan perusahaan secara lengkap dan turut membagikan dividen tunai selama 5 tahun dari tahun 2012 sampai 2016.

3. Laporan keuangan yang memiliki data yang lengkap untuk dapat mengukur variabel dividend payout ratio, profitability, firm size, liquidity, leverage dan sales growth.

Metode analisis yang digunakan untuk mendukung hasil penelitian ini adalah metode analisis regresi linear berganda yang digunakan untuk pengujian hipotesis antara variabel independen (variabel bebas) terhadap variabel dependen (variabel terikat) untuk memberikan bukti apakah terjadi pengaruh signifikan atau tidak (Indriantoro \& Supomo, 2013).

Metode ini digunakan untuk dapat mengembangkan sebuah persamaan atau model yang menjelaskan pengaruh antara variabel independen terhadap variabel dependen. Dengan menggunakan software SPSS versi 24 untuk menganalisis regresi linear berganda yang dianalisa dengan tahapan uji asumsi klasik, uji hipotesis dan uji statistik deskriptif.

\section{HASIL PENELITIAN}

Data yang digunakan dalam penelitian ini adalah data sekunder. Data yang dijadikan dalam sampel penelitian ini merupakan hasil laporan keuangan yang terdata dalam tahunan dan telah diaudit yang diperoleh dari perusahaan yang terdaftar di Bursa Efek Indonesia dalam periode dari 2012 sampai dengan 2016. Data yang telah diperoleh akan diproses dengan menggunakan program SPSS versi 24. Daftar emiten yang menjadi sampel pada penelitian ini dapat dilihat pada Tabel 1 di bawah ini: 
Tabel 1

Jumlah Emiten yang Dijadikan Sebagai Sampel

\begin{tabular}{ll}
\hline Keterangan & Jumlah \\
\hline Emiten di Bursa Efek Indonesia 2012-2016 & 540 Perusahaan \\
Emiten yang tidak memenuhi kriteria & 463 Perusahaan \\
Emiten yang memenuhi kriteria & 77 Perusahaan \\
Tahun penelitian & 5 tahun \\
Keseluruhan data penelitian & 385 data \\
Data outlier & 80 data \\
Data observasi & 305 data \\
\hline
\end{tabular}

Sumber: Data sekunder diolah (2018).

\title{
Uji Statistik Deskriptif
}

Tabel 2

Statistik Deskriptif

\begin{tabular}{lllllc}
\hline & N & Min. & Max. & Mean & $\begin{array}{c}\text { Standard } \\
\text { Deviasi }\end{array}$ \\
\hline Dividend Payout Ratio & 305 & 0,03461 & 1,04613 & 0,32615 & 0,19568 \\
\hline Profitability & 305 & 0,00307 & 0,43170 & 0,10356 & 0,07855 \\
\hline Firm Size & 305 & 11,1458 & 14,4180 & 12,7986 & 0,63405 \\
\hline Liquidity & 305 & 0,58422 & 9,71692 & 2,38544 & 1,64991 \\
\hline Leverage & 305 & 0,13059 & 0,86574 & 0,44686 & 0,18214 \\
\hline Sales Growth & 305 & $-0,31990$ & 0,74837 & 0,11240 & 0,15734 \\
\hline Valid N & 305 & & & & \\
\hline
\end{tabular}

Sumber: Data sekunder diolah (2018).

\section{Uji Heteroskedastisitas}

\author{
Gambar 1
}

Hasil Uji Heteroskedastisitas Model Regresi

Scatterplot

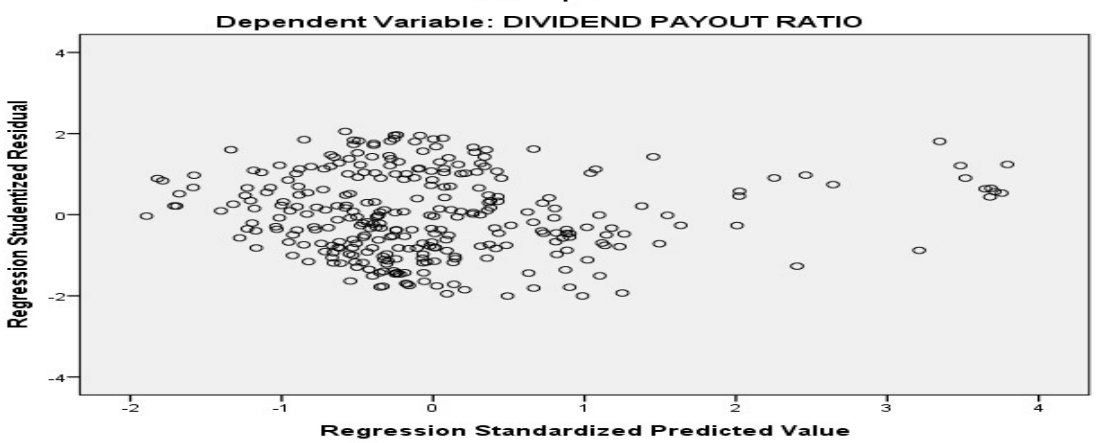

Sumber: Data sekunder diolah (2018).

\section{Uji Multikolinieritas}

Tabel 3

Hasil Uji Multikolinieritas

\begin{tabular}{lccc}
\hline \multicolumn{1}{c}{ Variabel } & Tolerance & VIF & Keterangan \\
\hline Profitability & 0,894 & 1,119 & Tidak terjadi multikolinieritas \\
\hline Firm Size & 0,984 & 1,016 & Tidak terjadi multikolinieritas \\
\hline
\end{tabular}




\begin{tabular}{llll}
\hline Liquidity & 0,549 & 1,823 & Tidak terjadi multikolinieritas \\
\hline Leverage & 0,500 & 2,001 & Tidak terjadi multikolinieritas \\
\hline Sales Growth & 0,942 & 1,062 & Tidak terjadi multikolinieritas \\
\hline \hline
\end{tabular}

Sumber: Data sekunder diolah (2018).

\section{Uji Autokorelasi}

Tabel 4

Hasil Uji Autokorelasi

\begin{tabular}{ccc}
\hline Model & DW & Keterangan \\
\hline Dividend Payout Ratio & 1,277 & Tidak terjadi autokorelasi \\
\hline
\end{tabular}

Sumber: Data sekunder diolah (2018).

\section{Uji Normalitas}

Tabel 5

Hasil Uji Normalitas

\begin{tabular}{lcc}
\hline Variabel Dependen & Kolmogorov Smirnov & Kesimpulan \\
\hline Dividend payout ratio & 0,181 & Normalitas \\
\hline Sumber: Data sekunder diolah (2018). & &
\end{tabular}

\section{Uji F}

Tabel 6

Hasil Uji F

\begin{tabular}{lcc}
\hline Variabel Dependen & Sig. & Kesimpulan \\
\hline Dividend Payout Ratio & 0,000 & Signifikan \\
\hline Sumber: Data sekunder diolah (2018). & &
\end{tabular}

\section{Uji t}

Tabel 7

Hasil Uji t

\begin{tabular}{|c|c|c|c|c|}
\hline \multirow[t]{2}{*}{ Variabel } & \multicolumn{2}{|c|}{$\begin{array}{c}\text { Unstandardized } \\
\text { Coefficients }\end{array}$} & \multirow[t]{2}{*}{ Sig. } & \multirow[t]{2}{*}{ Keterangan } \\
\hline & B & Std. Error & & \\
\hline (Constant) & $-0,142$ & 0,160 & 0,374 & \\
\hline Profitability & 1,766 & 0,101 & 0,000 & Signifikan Positif \\
\hline Firm Size & 0,031 & 0,012 & 0,010 & Signifikan Positif \\
\hline Liquidity & $-0,017$ & 0,006 & 0,007 & Signifikan Negatif \\
\hline Leverage & $-0,091$ & 0,058 & 0,121 & Tidak Signifikan \\
\hline Sales Growth & $-0,286$ & 0,049 & 0,000 & Signifikan Negatif \\
\hline \multicolumn{5}{|c|}{ Variabel Dependen: Dividend Payout Ratio } \\
\hline
\end{tabular}

$\mathrm{H}_{1}$ : $\quad$ Profitability memiliki pengaruh signifikan positif terhadap Dividend Payout Ratio. 
Perusahaan yang memiliki tingkat profitabilitas yang tinggi akan membuat perusahaan memiliki banyak dana sehingga perusahaan mampu membayar dividen kepada para investor meskipun sebagian laba yang ditahan untuk kepentingan perusahaan sehingga para investor cenderung menanamkan modal pada perusahaan yang memiliki tingkat profitabilitas tinggi agar mendapatkan keuntungan yang lebih banyak. Uji hipotesis pertama diterima.

\section{$\mathrm{H}_{2}: \quad$ Firm Size memiliki pengaruh signifikan positif terhadap Dividend Payout Ratio.}

Perusahaan dengan ukuran yang besar lebih cenderung membayar dividen lebih tinggi daripada perusahaan yang kecil karena perusahaan yang besar memiliki kemudahan akses dalam menuju menuju pasar modal sehingga perusahaan dapat memperoleh dana dan keuntungan yang lebih besar. Perusahaan dengan ukuran yang besar cenderung tidak memerlukan dana yang banyak untuk memperluas operasi mereka dikarenakan perusahaan besar memiliki peluang pertumbuhan yang lebih rendah dibandingkan perusahaan kecil yang memerlukan dana sehingga menahan laba yang lebih banyak untuk melakukan investasi perkembangan perusahaan. Uji hipotesis kedua diterima.

\section{$\mathrm{H}_{3}$ : $\quad$ Liquidity memiliki pengaruh signifikan positif terhadap Dividend Payout Ratio.}

Liquidity yang tinggi belum tentu mampu membayar dividen yang baik. Hal ini dikarenakan perusahaan tidak mampu menggunakan kas dengan baik sehingga perusahaan yang memiliki tingkat likuiditas yang tinggi justru menunjukkan perusahaan tersebut tidak mampu mengelola aset dengan baik atau tidak efektif dalam menggunakan modal kerja yang disebabkan oleh keseimbangan dari current asset yang tidak menguntungkan sehingga menyebabkan rasio pembayaran dividen kepada investor semakin kecil. Bukti empiris bahwa hubungan antara variabel liquidity terhadap dividend payout ratio memiliki pengaruh signifikan negatif yaitu pada perusahaan Fast Food Indonesia Tbk (FAST) dimana pada tahun 2014 memiliki nilai liquidity sebesar 1,882 dengan nilai DPR sebesar 0,393. Pada tahun 2015 nilai liquidity menurun sebesar 1,261 dengan nilai DPR yang meningkat sebesar 0,569. Pada tahun 2016 nilai liquidity mengalami peningkatan sebesar 1,793 dengan nilai DPR yang menurun sebesar 0,231. Hal ini membuktikan bahwa adanya penurunan liquidity akan meningkatkan dividend payout ratio sedangkan adanya peningkatan liquidity akan menurunkan nilai dividend payout ratio. Sehingga uji hipotesis ketiga ditolak.

\section{$\mathrm{H}_{4}$ : Leverage memiliki pengaruh signifikan negatif terhadap Dividend Payout Ratio.}

Leverage tidak memiliki pengaruh signifikan terhadap Dividend Payout Ratio, hal ini menunjukan bahwa kemampuan perusahaan dalam membayar dividen secara teratur tidak dipengaruhi oleh seberapa besar kecilnya hutang perusahaan. Perusahaan telah menetapkan kebijakan dividen terlebih dahulu sebelum perusahaan melakukan pelunasan hutangnya. Pelunasan hutang yang dapat dilakukan oleh perusahaan antara lain dengan menerbitkan obligasi baru atau dibiayai dari laba ditahan.

\section{$\mathrm{H}_{5}$ : Sales Growth memiliki pengaruh signifikan negatif terhadap Dividend Payout Ratio.}

Hasil penelitian diatas menunjukkan hasil yang sama dengan hipotesis penulis dimana Sales Growth memiliki pengaruh signifikan negatif pada Dividend Payout Ratio. Hal ini dikarenakan meningkatnya pertumbuhan penjualan perusahaan yang semakin tinggi akan membutuhkan lebih banyak dana untuk membiayai pertumbuhan perusahaan dalam berinvestasi proyek-proyeknya sehingga perusahaan akan mempertahankan proporsi pendapatan mereka yang lebih besar dengan membayar dividen yang rendah daripada meminjam dana eksternal yang memiliki biaya bunga yang lebih mahal.

\section{Uji Koefisien Determinasi}

Tabel 8

Hasil Uji Koefisien Determinasi

Variabel Dependen
Std. Error of The Estimate 


\begin{tabular}{ccc}
\hline Dividend payout ratio & 0,550 & 0,1581 \\
\hline
\end{tabular}

Sumber: Data sekunder diolah (2018).

Pada Tabel 8 diatas, menunjukkan nilai adjusted $R^{2}$ pada variabel Dividend Payout Ratio adalah 0,550 yang berarti bahwa sebesar 55\% variabel Dividend Payout Ratio dapat dijelaskan oleh variabel Profitability, Firm Size, Liquidity, Leverage dan Sales Growth. Sedangkan sisanya sebesar $45 \%$ dijelaskan oleh faktor-faktor lain di luar model regresi ini.

\section{KESIMPULAN}

Berdasarkan hasil pengujian serta analisis pengaruh profitability, firm size, liquidity, leverage dan sales growth terhadap dividend payout ratio pada bab sebelumnya, maka dapat disimpulkan bahwa:

1. Profitability memiliki pengaruh signifikan positif terhadap Dividend Payout Ratio. Hal ini dapat disimpulkan bahwa perusahaan yang memiliki tingkat profitabilitas yang tinggi akan membuat perusahaan memiliki banyak dana sehingga perusahaan mampu membayar dividen kepada para investor meskipun sebagian laba yang ditahan untuk kepentingan perusahaan sehingga para investor cenderung menanamkan modal pada perusahaan yang memiliki tingkat profitabilitas tinggi agar mendapatkan keuntungan yang lebih banyak. Hasil penelitian memiliki hasil yang sesuai dengan hipotesis dan didukung oleh Tabari dan Shirazi (2015), Milhem (2016), Leon dan Putra (2014), Wijaya dan Felix (2017), Fitri et al. (2016) dan Aftab et al. (2017). Namun terdapat beberapa penelitian yang tidak memiliki hasil yang sesuai dengan penelitian oleh Gill et al. (2010), Badu (2013), Thu et al. (2013), Demirgunes (2015), Saeed et al. (2014) dan Rafique (2012). Kesimpulan dari uji $\mathrm{t}$ untuk hipotesis pertama diterima.

2. Firm Size memiliki pengaruh signifikan positif terhadap Dividend Payout Ratio. Perusahaan dengan ukuran yang besar lebih cenderung membayar dividen lebih tinggi daripada perusahaan yang kecil karena perusahaan yang besar memiliki kemudahan akses dalam menuju menuju pasar modal sehingga perusahaan dapat memperoleh dana dan keuntungan yang lebih besar. Dan hasil penelitian tersebut terdapat beberapa penelitian yang didukung dan sesuai oleh penelitian Tabari dan Shirazi (2015), Maladjian dan Khoury (2014), Ahmad dan Wardani (2014) dan Awad (2015). Namun hasil penelitian ini tidak sesuai hipotesis dengan penelitian oleh Thu et al. (2013), Yusuf dan Muhammed (2015), Khan dan Ahmad (2017), Wijaya dan Felix (2017) dan Hashim (2017). Kesimpulan dari uji t untuk hipotesis kedua diterima.

3. Liquidity memiliki pengaruh signifikan negatif terhadap Dividend Payout Ratio. Hal ini menunjukkan bahwa liquidity yang tinggi belum tentu mampu membayar dividen yang baik. Hal ini dikarenakan perusahaan tidak mampu menggunakan kas dengan baik sehingga perusahaan yang memiliki tingkat likuiditas yang tinggi justru menunjukkan perusahaan tersebut tidak mampu mengelola aset dengan baik atau tidak efektif dalam menggunakan modal kerja yang disebabkan oleh keseimbangan dari current asset yang tidak menguntungkan sehingga menyebabkan rasio pembayaran dividen kepada investor semakin kecil. Hasil tersebut didukung dan sesuai dengan hipotesis oleh penelitian Ahmad dan Wardani (2014), John dan Muthusamy (2010) dan Yusuf dan Muhammed (2015). Namun hasil penelitian ini tidak sesuai hipotesis dengan penelitian oleh Tabari dan Shirazi (2015), Patrick et al. (2017), Maldajian dan Khoury (2014), Demirgunes (2015), Komrattanapanya dan Suntraruk (2013), Milhem (2016), Wijaya dan Felix (2017) dan Hashim (2017). Kesimpulan dari uji t untuk hipotesis ketiga ditolak.

4. Leverage tidak memiliki pengaruh signifikan terhadap Dividend Payout Ratio. Hal ini menunjukan bahwa kemampuan perusahaan dalam membayar dividen secara teratur tidak dipengaruhi oleh seberapa besar kecilnya hutang perusahaan. Perusahaan telah menetapkan kebijakan dividen terlebih dahulu sebelum perusahaan melakukan pelunasan hutangnya. Pelunasan hutang yang dapat dilakukan oleh perusahaan antara lain dengan menerbitkan obligasi baru atau dibiayai dari laba ditahan. Hasil penelitian ini didukung dan sesuai hipotesis oleh penelitian Obembe et al. (2014), Patrick et al. (2017), Wara (2015), Wijaya dan Felix (2017) dan Hashim (2017). Namun hasil 
penelitian ini tidak sesuai hipotesis dengan penelitian oleh Hosain (2016), Malik et al. (2013), Awad (2015), Sanjari dan Zarei (2015), Ullah et al. (2012) dan Thu et al. (2013). Kesimpulan dari uji t untuk hipotesis keempat ditolak.

5. Sales Growth memiliki pengaruh signifikan negatif terhadap Dividend Payout Ratio. Hal ini dikarenakan meningkatnya pertumbuhan penjualan perusahaan yang semakin tinggi akan membutuhkan lebih banyak dana untuk membiayai pertumbuhan perusahaan dalam berinvestasi proyek-proyeknya sehingga perusahaan akan mempertahankan proporsi pendapatan mereka yang lebih besar dengan membayar dividen yang rendah daripada meminjam dana eksternal yang memiliki biaya bunga yang lebih mahal. Hasil penelitian tersebut didukung dan sesuai hipotesis oleh penelitian adalah adalah John dan Muthusamy (2010), Amidu dan Abor (2006), Sanjari dan Zarei (2015), Wara (2015), Demirgunes (2015), Malik et al. (2013), Maldajian dan Khoury (2014), Fitri et al. (2016) dan Thu et al. (2013). Namun terdapat beberapa hasil penelitian yang tidak sesuai dan didukung oleh penelitian Tabari dan Shirazi (2015), Musiega et al. (2013), Rafique (2012), Tahir dan Mushtaq (2016), Ahmad dan Wardani (2014) dan Aftab et al. (2017). Kesimpulan dari uji t untuk hipotesis kelima diterima.

\section{DAFTAR PUSTAKA}

Aftab, F., Khan, R., Meer, J. K., \& Lodhi, R. N. (2017). Determinants of Dividend Payout Ratio: A Study of Textile Sector of Pakistan. Journal of Business Studies, 13(1), 12-24.

Ahmad, G. N., \& Wardani, V. K. (2014). the Effect of Fundamental Factor To Dividend Policy: Evidence in Indonesia Stock Exchange. Business and Commerce, 4(2), 14-25. Retrieved from http://www.ijbcnet.com/4-2/IJBC-14-31101.pdf

Amidu, M., \& Abor, J. (2006). Determinants of dividend payout ratios in Ghana. The Journal of Risk Finance, 7(2), 136-145. https://doi.org/10.1108/15265940610648580

Anil, K., \& Kapoor, S. (2008). Determinants of Dividend Payout Ratios-A Study of Indian Information Technology Sector. International Research Journal of Finance and Economics, 15(15), 63-71.

Awad, D. B. (2015). Determinants of Dividend Policy in Kuwait Stock Exchange. International Journal of Business and Management Review Vol.3, 3(7), 72-78.

Badu, E. A. (2013). Determinants of Dividend Payout Policy of listed Financial Institutions in Ghana. Research Journal of Finance and Accounting, 4(7), 2222-2847. https://doi.org/10.2298/PAN1306725N

Caesario, E. B. (2017). Meski Laba Bersih Turun, LION Bayar Dividen Rp40 per Saham. Dikutip dari: https//market.bisnis.com/read/20170606/192/659811/meski-laba-bersih-turun-lion-bayar-dividenrp40-per-saham

Demirgunes, K. (2015). Determinants of Target Dividend Payout Ratio: A Panel Autoregressive Distributed Lag Analysis. International Journal of Economics and Financial Issues, 5(2), 418-426.

Destrianita. (2017). Laba usaha turun, anak usaha lippo karawaci tetap bagi dividen. Dikutip dari: https://bisnis.tempo.co/read/857969/laba-usaha-turun-anak-usaha-lippo-karawaci-tetap-bagidividen/full\&view $=$ ok

Ehsan, S., Tabassum, N., Akram, Z., \& Nasir, R. (2013). Role of Insider and Individual Ownership Structure in Dividend Payout Policy: Evidence from Pakistan. Middle-East Journal of Scientific, 17(9), 1316-1326. https://doi.org/10.5829/idosi.mejsr.2013.17.09.12304

Fitri, R. R., Hosen, M. N., \& Muhari, S. (2016). Analysis of Factors that Impact Dividend Payout Ratio on Listed Companies at Jakarta Islamic Index. International Journal of Academic Research in Accounting, Finance and Management Sciences, 6(2), 87-97. https://doi.org/10.6007/IJARAFMS/v6-i2/2074

Ghozali, I. (2013). Aplkasi Analisis Multivariate Dengan Program SPSS. Semarang: Badan Penerbit Undip.

Gill, A., Biger, N., \& Tibrewala, R. (2010). Determinants of Dividend Payout Ratios: Evidence from United States. The Open Business Journal, 3, 8-14. https://doi.org/10.2174/1874915101003010008

Hashim, S. L. B. M. (2017). Analysis on Dividend Payout: Empirical Evidence of Property Companies in Malaysia. International Journal of Industrial Management (IJIM) ISSN, 3, 61-71. 
Hosain, M. Z. (2016). Determinants of the Dividend Payout Policy: A Study on Listed Private Commercial Banks of Dhaka Stock Exchange Limited in Bangladesh. IOSR Journal of Economics and Finance (IOSR-JEF), 7(5), 1-10. https://doi.org/10.9790/5933-0705040110

Indriantoro, N., \& Supomo, B. (2013). Metodologi Penelitian Bisnis untuk Akuntasi \& Manajemen. Yogyakarta: Fakultas Ekonomika dan Bisnis UGM.

Issa, A. I. F. (2015). The Determinants of Dividend Policy: Evidence from Malaysian Firms. Research Journal of Finance and Accounting, 6(18), 69-87.

John, S. F., \& Muthusamy, K. (2010). Leverage, Growth and Profitability as Determinants of Dividend Payout Ratio-Evidence from Indian Paper Industry. Asian Journal of Business Management Studies, 1(1), 26-30.

Khan, F. A., \& Ahmad, N. (2017). Models for online grocery shopping - a study of Pakistani online market. Journal of Financial Studies \& Research, 2017, 16 pages. https://doi.org/10.5171/2017.538214

Khan, M. N., Naeem, M. U., Rizwan, M., \& Salman, M. (2016). Factors Affecting the Firm Dividend Policy: An Empirical Evidence from Textile Sector of Pakistan. International Journal of Advanced Scientific Research and Management, 1(5), 144-149. Retrieved from www.ijasrm.com

Komrattanapanya, P., \& Suntraruk, P. (2013). Factors Influencing Dividend Payout in Thailand: A Tobit Regression Analysis. International Journal of Accounting and Financial Reporting, 3(2), 255. https://doi.org/10.5296/ijafr.v3i2.4443

Labhane, N. B., \& Das, R. C. (2015). Determinants of Dividend Payout Ratio: Evidence from Indian Companies. Business and Economic Research, 5(2), 217. https://doi.org/10.5296/ber.v5i2.8154

Leon, F. M., \& Putra, P. M. (2014). The Determinant Factor of Dividend Policy at Non Finance Listed Companies. International Journal of Engineering, Business and Enterprise Applications (IJEBEA ), 22-26.

Maldajian, C., \& El Khoury, R. (2014). Determinants of the Dividend Policy: An Empirical Study on the Lebanese Listed Banks. International Journal of Economics and Finance, 6(4), 240-256. https://doi.org/10.5539/ijef.v6n4p240

Malik, F., Gul, S., Khan, M. T., \& Rehman, S. U. (2013). Factors Influencing Corporate Dividend Payout Decisions of Financial and Non-Financial Firms. Research Journal of Finance and Accounting, 4(1), 2222-2847.

Milhem, M. M. (2016). Determinants of Dividend Policy: A Case of Banking Sector in Jordan. MiddleEast Journal of Scientific, 1411-1422.

Musiega, M. G., Alala, O. B., Douglas, M., Christopher, M. O., \& Robert, E. (2013). Determinants Of Dividend Payout Policy Among Non-Financial Firms On Nairobi Securities Exchange, Kenya. International Journal of Scientific \& Technology Research, 2(10), 253-266. Retrieved from www.ijstr.org

Obembe, O., Imafidon, J., \& Adegboye, A. (2014). Product Market Competition and Dividend Payouts of Listed Non-Financial Firms in Nigeria. International Journal of Economics and Finance, 6(11), 117-131. https://doi.org/10.5539/ijef.v6n11p117

Patrick, D. Z., Theophilus, M. M. A., \& Mirian, M. M. (2017). Determinants of Dividend Policy of petroleum firms in Nigeria. IOSR Journal of Economics and Finance, 8(3), 54-62. https://doi.org/10.9790/5933-0803045462

Rafique, M. (2012). Factors Affecting Dividend Payout: Evidence From Listed Non-Financial Firms of Karachi Stock Exchange. Business Management Dynamics, 1(11), 76-92.

Saeed, R., Riaz, A., Lodhi, R. N., Munir, H. M., \& Iqbal, A. (2014). Determinants of Dividend Payouts in Financial Sector of Pakistan. Journal of Basic and Applied Scientific Research, 4(2), 33-42.

Sanjari, T., \& Zarei, B. (2015). The Study Factors Influencing Corporate Dividend Policy of Financial and Non-Financial Firms on Companies Listed In Tehran Stock Exchange. Research Journal of Finance and Accounting, 5(21), 138-144. Retrieved from www.iiste.org

Santoso, S. (2014). Statistik Parametik Konsep dan Aplikasi dengan SPSS Versi Revisi. Jakarta: Elex Media Komputindo.

Sinabutar, A., \& Nugroho, A. B. (2015). Dividend Payout Ratio in Indonesian Consumer Goods Industry: Panel Analysis and Determinant Factors in 2004-2013. Journal of Business and Management, 4(4), 
$453-464$.

Sugiarto, T. (2015). Cash Ratio, Return on Assets, Debt To Equity Ratio and Dividend Payout Ratio of 25 Companies Listed in BEI Period 2005-2014 Test Data Using Panel, 2(1), 2349-5677.

Sugiono. (2012). Memahami Penelitian Kualitatif. Bandung: Alfabeta.

Tabari, N. A. Y. Z., \& Shirazi, S. (2015). Examining the Determinants of Dividend Policy in Listed Companies in Tehran Stock Exchange. Indian Journal of Fundamental and Applied Life Sciences, 5, 2375-2382. Retrieved from www.cibtech.org/sp.ed/jls/2015/03/jls.htm

Tahir, M., \& Mushtaq, M. (2016). Determinants of Dividend Payout: Evidence from listed Oil and Gas Companies of Pakistan. The Journal of Asian Finance, Economics and Business, 3(4), 25-37. https://doi.org/10.13106/jafeb.2016.vol3.no4.25

Thu, N. K., Trien, L. V., Anh, D. T. T., \& Nhom, H. T. (2013). Determinants of Dividend Payments of Non-financial Listed Companies in H ồ Chí Minh Stock Exchange. The Journal of Economics and Business, 29(5), 16-33.

Ullah, H., Fida, A., \& Khan, S. (2012). The impact of ownership structure on dividend policy evidence from emerging markets KSE-100 index Pakistan. International Journal of Business and Social Science, 3(9), 298-307.

Wara, R. K. (2015). Determinants of Dividend Payout Ratios in Kenya. Research Journal of Finance and Accounting, 6(1). Retrieved from www.iiste.org

Wijaya, N., \& Felix, A. (2017). Factors Affecting Dividend Policy on Non-Financial Companies in Indonesia. Global Academy of Training \& Research (GATR) Enterprise, 2(3), 18-25. Retrieved from www.gatrenterprise.com/GATRJournals/index.html Acc.

Yusuf, A., \& Muhammed, N. (2015). Determinant of dividend payout in Nigerian banking industry. Scholars Bulletin, 1(9), 253-259.

Yusuf, B. R. (2015). Dividend payout ratio and performance of deposit money banks in Nigeria. International Journal of Advances in Management and Economic, 4(6), 98-105. Retrieved from http://www.managementjournal.info 